J. Soc. Brew. Japan, 1971, Vol. 66, No. 2, p. 176 p. 180

$$
\begin{gathered}
\text { ビール中のフェノール性物質の比較* } \\
\text { 大塚謙一・チン・キム・チェン・脇田征也 }
\end{gathered}
$$

（国税庁醇造試験所）

昭和 45 年 8 月 17 日受理

\begin{abstract}
製品ビン詰ビールを中性下括よび酸性下で酢酸エチルにて抽出し，さらに食塩飽和下でアセトン抽 出を行ない, 各抽出区について Folin-Denis 試薬による発色を比色した。これらの比色值をフェノー ル成分の対応值と考光, 各種のビールについて比較した。同一工場でのロット別ビールの各フェノー ル区分は製造時日の近いものでは変動が小さく, 同一会社の工場別ビールではアセトン区分の变動が より大きいものが認められた。

各国ビールについて比較すると, 国産品はアセトン区分以外は類似の值を示し, 外国産のものは酸 性区分以外は変動の大きなるのが認められ，フェノール量からもビールのタイプの異同を示唆できる ものと考えられる。

さらに各フェノール区分についてシリカカラムクロマトグラフィーを行ない，ビールの銘柄別に比 較した結果, 特にアセトン抽出区分のクロマトグラムのパターンに 2,3 のタイプのあることが認めら れた。
\end{abstract}

\section{緒}

\section{$\overline{\overline{\overline{⿳ 亠 口 冋}}}$}

ビールに含まれるフェノール類は原料，副原料，ホッ プ等から由来するが，この他に酵母の生産物もチロゾー ルを始めいくつかのものが考觉られるこれらは大別し てアントシアノーゲン, タンニン (ポリフェノール), フエノール 類である。これらについては Harris の一 連の研究1) 始め, Chapon ${ }^{2)}$, McFarlane ${ }^{3)}$, Curtis ${ }^{4)}$, Pollock $^{5)}$ Meredith $^{6)}$, Krauss ${ }^{7)}$, Woof ${ }^{8)}$, Nakayama ${ }^{9)}$, Kleber ${ }^{10)}$, Reynolds ${ }^{11)}$, Schuster ${ }^{12)}$ 等多くの研 究が発表されている。これらのらち phenol 類について ビール間で比較を行なったものとしては Nakayama9) が, Folin-Denis 法, 紫外線吸收, Nylon 吸着の三つの 方法を用いて夫々の值を比較した報告と, Harris が 4 種のビールの haze 中のメトキシフェノール酸, ガリッ ク酸, プロトカテキュ酸, カフェイン酸の量的比較した 報告がある。また McFarlene ら³がビール中のチロゾー ル，トリプトフォールを定量して和り，チロゾールは 18〜40 mg/l としている。

著者らは前報 ${ }^{13)}$ に示した䣫酸エチルによる分別抽出法 にさらにアセトン抽出を附加して，これら抽出部につい て Folin-Denis 試薬でフェノール類を定量し，ビール間 の量的比較を行なった結果, 二, 三の知見が得られたの

*酒類のフェノール性物質に関する研究（第 4 報）
で報告する。

\section{実験}

\section{試 料}

国産および外国産のビン詰ビールを用いた。国産品は キリン, サッポロ, アサヒ, タカラ, サントリーの 5 社 の製品であり，外国産はドイッ（ホルステン，ドルトム ソト, レーベンブロイ, ヘック), デンマーク（カール スベルヒ，ツボルク），チェコスロバキヤ（ピルスナー ウルケル)，アメリカ(バッドワィザー), オーストラリ ア (スワン)，イギリス (ギネス) のものである。

これらは昭和 $40 \sim 41$ 年に購入または入手したもので, 分析は昭和 41 年に行なった。

\section{分析方法}

（1）中性フェノール区分。攪拌により脱炭酸後の試 料 $10 \mathrm{ml}$ を分液口ートにとり, $\mathrm{Na}_{2} \mathrm{CO}_{3}$ にて $\mathrm{pH} 7.2$ 迄 中和し，これに酰酸エチル $10 \mathrm{ml}$ を加光，15分間振と う抽出する。非抽出部にさらに酢酸エチル $7 \mathrm{ml}$ を加兄, 同様に抽出する。つづいて䣫酸エチル $5 \mathrm{~m} l$ にて第 3 回 目の抽出を行い，酢酸エチル層は芒硝にて脱水後合一し て同一溶媒にて $25 \mathrm{~m} l$ にみたす。

（2）酸性フェノール区分。中性フェノールを抽出し た残液を硫酸にて $\mathrm{pH} 3$ 以下にして, 酢酸エチル 10,7 , $5 \mathrm{ml}$ の 3 回抽出を行ない, 抽出部を脱水後合して $25 \mathrm{ml}$ 
大塚・チェン・脇田：ビール中のフェノール性物質の比較

にみたす。

（3）アセトン抽出区分。酸性フェノールを抽出した 残液に食塩 $5 \mathrm{~g}$ を加光, アセトン $10,7,5 \mathrm{ml}$ の 3 回 抽出を行い，同じく $25 \mathrm{~m} l$ にみたす。

（4）総フェノール。脱炭酸したビール $2 \mathrm{ml}$ を水に て $25 \mathrm{~m} l$ に希釈する（この中にはチロシンも含まれる）。

（5） Folin-Denis 試薬による発色と比色。抽出液で. は $1.0 \mathrm{ml}$, 総フェノールでは $0.5 \sim 1.0 \mathrm{ml}$, 後述するク ロマト溶出液では $0.2 \mathrm{ml}$ を試験管にとり, 水以外の溶 媒の場合は減圧下で溶媒を駆逐し, 水 $1.0 \mathrm{~m} l$ に溶かし, これに $0.4 \mathrm{M}-\mathrm{Na}_{2} \mathrm{CO}_{3}$ 溶液 $5.0 \mathrm{ml}$, Folin-Denis 試薬 (3 倍希釈) $1.0 \mathrm{ml}$ を加光, 摼挥後 $30^{\circ} \mathrm{C}$ に置き, 30 分 後 $660 \mathrm{~m} \mu$ にて比色した。得られた対数値 (O.D.) 值を 中性酢エチル抽出部は tyrosol, 酸性酢エチ抽出部は ferulic acid, アセトン抽出部は gallic acid, 総フェノ ールは tannic acid として各検量線より算出し, ビール $100 \mathrm{~m} l$ 当りに換算した。

（6） シリカカラムクロマトグラフィー。カラムは Mallinckrodt 製けい酸 $20 \mathrm{~g}$ を用いて作り, 試料を充填 後, クロロホルムーエタノール系溶媒 $50 \mathrm{ml}$ づつで展開 溶出した。溶出液はフラクションコレクターにて $10 \mathrm{~g}$ づつ分取した。この際の溶媒組成は中性和よび酸性酢工 于抽出部の場合はクロロホルム混和率 100, 95, 90, 85, $80,70,60 \%$ を用い, アセトン溶出部の場合は 90,80 , $70 ， 60 ， 50 ， 40 ， 20 \%$ を用いた。試料はビール $200 \mathrm{ml}$ を用い前項と同様の比率で，中性拉よび酸性酢酸エチル 抽出部さらにアセトン抽出部を得，これを脱水後減圧下 で濃縮した。

カラム溶出液は $0.5 \mathrm{~m} l$ (濃厚の場合は $0.1 \sim 0.2 \mathrm{ml}$ ) を試験管にとり，減圧下で溶媒駆逐後，水 $1.0 \mathrm{ml}$ に溶 解して Folin-Denis 試薬にて発色させた。カラム溶出液 は溶媒組成の変化と共に液量が増加するので, 全液量を 計量して, 比色值から検量線で得た值を全液量に換算し た。

（7）沪紙クロマトグラフィー。東洋沪紙 No. 50 を あらかじめ $0.1 \mathrm{M} \mathrm{Na}_{2} \mathrm{HPO}_{4}-\mathrm{KH}_{2} \mathrm{PO}_{4}$ の緩衝液 ( $\mathrm{pH} 7.2$ ) に浸漬し風乾した。これに試料をスポットして sec-ブタ ノ一ル: 水 $=4: 1$ にて一晚上昇法にて展開して, 風乾 後紫外線吸収または蛍光を検し，さらにジアゾ化ベンゼ ソスルファニール酸, 炭酸ソーダ液にて spray して発 色させた。

\section{結果}

\section{I. ロット別ビールのフェノール量の比較}

$\mathrm{A}$ 社の同一工場のビン詰ビールを用いたが，その内訳
第1表 ロット別ビール中のフェノール量の比較

\begin{tabular}{|c|c|c|c|c|c|}
\hline \multirow{2}{*}{ ロット番号 } & \multirow{2}{*}{ 製造月日 } & \multirow{2}{*}{$\begin{array}{l}\text { 総フェ } \\
\text {-ル1 }\end{array}$} & \multicolumn{2}{|c|}{ 酢エチ抽出部 } & \multirow{2}{*}{$\begin{array}{l}\text { アセトン } \\
\text { 抽出部 } 4 \text { (2) }\end{array}$} \\
\hline & & & $\overparen{\text { 中性2) }}$ & 酸性 33 & \\
\hline A-1 & 10.7 & 37.5 & 3.8 & 2.5 & 19.3 \\
\hline A-2 & 12.1 & 47.5 & 4.5 & 3.0 & 20.7 \\
\hline A-3 & 12.2 & 42.5 & 4.6 & 3.9 & 19.5 \\
\hline A-4 & 12.9 & 42.0 & 5.5 & 3.9 & 20.3 \\
\hline$A-5$ & 12.12 & 42.5 & 4.4 & 2.8 & 17.4 \\
\hline \multicolumn{2}{|c|}{$\bar{x}_{1 \sim 5}$} & 42.50 & 4.56 & 3.22 & 19.44 \\
\hline \multicolumn{2}{|c|}{$s$} & 3.15 & 0.47 & 0.58 & 1.14 \\
\hline \multirow{2}{*}{\multicolumn{2}{|c|}{$\begin{array}{l}\bar{x}_{2 \sim 5} \\
s\end{array}$}} & 43.63 & 4.75 & 3.40 & 19.48 \\
\hline & $s$ & 2.21 & 0.47 & 0.50 & 2.52 \\
\hline $\begin{array}{l}\text { 1) } \\
\text { 3) }\end{array}$ & $\begin{array}{l}\text { Eannic ac } \\
\text { ferulic a }\end{array}$ & $\begin{array}{l}\text { 2) } \\
\text { 4) }\end{array}$ & \multicolumn{2}{|c|}{ as tyrosol } & \\
\hline
\end{tabular}

は 12 日間の 4 ロット (No. 2〜5) と 2 ケ月前の 1 ロッ ト（No.1）である。

第 1 袁に示すよ らに No. 1〜 5 と No. 2 5 の平均值及 び標準偏差 $(s)$ を比較してみると総フェノールの $s$ の 值が 5 点間の方がより大きくなるが，これはロットー1す なわち 2 ケ月前のロットの值がより低いためである。し かし各フェノール分画区の $s$ の值には大きな差はない。 したがって短期間内のロット間ではフェノール区分のバ ラッキはそれ程大きくないといえる。しかしこのデータ では試科数が少ないので明確でないが，このようなチェ ックにより工場での製品管理の一助になるものと考光ら れる。

\section{II. 工場別ビールのフェノール量の比較}

$\mathrm{B}, \mathrm{C}$ 社の工場別ビン詰ビールの比較を第 2 表に示す。 B 社の場合の各フェノール区分のバラシキをみるとアセ トン区分がやや大きいが総じてバラッキが小さいとい壳 る。C社ではアセトン区分が大きくバラッイていること がわかる。

地域的に離れた工場では設備，原料等の要因が異なる であろうから，ある程度のバラッキのあるのは当然とい えるが，官能的に大きな差が出ると問題である。

III. 国別ビールのフェノール量の比較

国産銘柄 5 点, ドイッ 4 点, デンマーク 2 点, チェコ,

第 2 表 工場別ビール中のフェノール量の比較 $(\mathrm{mg} / 100 \mathrm{ml}$ )

\begin{tabular}{|c|c|c|c|c|}
\hline \multirow{2}{*}{ 工場番号 } & \multirow{2}{*}{ 総フェノール1) } & \multicolumn{2}{|c|}{ 酰工チ抽出部 } & \multirow{2}{*}{ アセトン抽出部4) } \\
\hline & & 中 性 2 ) & 酸 性 3 ) & \\
\hline B-1 & 45.0 & 4.3 & 2.3 & 20.8 \\
\hline B-2 & 43.8 & 3.8 & 2.3 & 16.6 \\
\hline B-3 & 46.3 & 5.8 & 3.3 & 19.7 \\
\hline B-4 & 48.8 & 4.8 & 3.2 & 27.3 \\
\hline$\vec{x}$ & 45.98 & 4.70 & 2.78 & 21.10 \\
\hline$s$ & 1.90 & 0.74 & 0.48 & 3.89 \\
\hline $\mathrm{C}-1$ & 53.8 & 5.0 & 3.6 & 41.0 \\
\hline $\mathrm{C}-2$ & 48.8 & 5.0 & 3.0 & 27.0 \\
\hline $\mathrm{C}-3$ & 53.8 & 6.5 & 3.9 & 19.0 \\
\hline $\bar{x}$ & 52.13 & 5.50 & 3.50 & 29.0 \\
\hline$s$ & 2.99 & 0.70 & 0.37 & 9.1 \\
\hline $\begin{array}{ll}\text { 1) } & \mathrm{a} \\
\text { 3) } & \mathrm{a}\end{array}$ & $\begin{array}{l}\text { tannic acid } \\
\text { ferulic acid }\end{array}$ & $\begin{array}{l}\text { 2) as } \\
4 \text { ) as }\end{array}$ & $\begin{array}{l}\text { yrosol } \\
\text { allic aci }\end{array}$ & \\
\hline
\end{tabular}


第 3 表 銘柄別ビール中のフェノール量の比較 $(\mathrm{mg} / 100 \mathrm{ml})$

\begin{tabular}{|c|c|c|c|c|c|c|}
\hline 記号 & 国 別 & 産 & 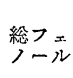 & 酰工天 & 抽出部部性 & $\begin{array}{l}\text { アセセトン } \\
\text { 抽出部 }\end{array}$ \\
\hline G- 1 & トィッ & ハンブルグ & 68.8 & 8.9 & 3.1 & 35.8 \\
\hline G- 2 & ドィッ & ドルトムント & 46.9 & 5.5 & 3.6 & 26.3 \\
\hline$G-3$ & ドィッ & $\Sigma=ン ヘ ン$ & 58.8 & 5.8 & 4.0 & 31.8 \\
\hline$G-4$ & ドィッ & ブレーメン & 62.5 & 5.5 & 3.9 & 20.0 \\
\hline$J-5$ & 日本 & & 45.0 & 4.3 & 2.3 & 20.8 \\
\hline$J-6$ & 本 & & 48.8 & 5.0 & 3.0 & 27.0 \\
\hline $\mathrm{J}-7$ & 本 & & 42.5 & 4.6 & 3.9 & 19.5 \\
\hline$J-8$ & 本 & & 48.7 & 4.5 & 3.5 & 26.8 \\
\hline$J-9$ & 日本 & & 46.9 & 5.5 & 3.8 & 23.0 \\
\hline $\mathrm{D}-10$ & デンマーク & コペンハーゲン & 39.4 & 4.6 & 3.3 & 22.7 \\
\hline D-11 & デンマーク & コペンハーダン & 49.4 & 5.5 & 2.9 & 19.0 \\
\hline C-12 & $F=z$ & ピルセン & 57.5 & 10.8 & 3.1 & 36.5 \\
\hline $\mathrm{U}-13$ & アメリカ & ロスアンゼルス & 36.3 & 2.5 & 4.6 & 24.0 \\
\hline$E-14$ & イギリス & & 121.3 & 14.4 & 8.2 & 54.0 \\
\hline
\end{tabular}

アメリカ, イギリス各 1 点について前項同様に各分画フ ェノール量を比較した。イギリスのものは特殊なもので あるので平均値の算出には除外した。

第 3〜4 表に示すように総フェノール量では国産品は $42.5 \sim 48.8 \mathrm{mg} / 100 \mathrm{ml}$ で平均 $46.4 \mathrm{mg} / 100$ $\mathrm{m} l$ であるが，ドイッのものは 46.9〜68.8 $\mathrm{mg} / 100 \mathrm{ml}$ と巾が広く, 平均も $59.2 \mathrm{mg} / 100$ $\mathrm{m} l$ でより高い值を示した。デンマークの 1 点特よびアメリカのものは少ない。イギリス のものはタイプが異るためか大きな值を示し た。

中性酢エチ 抽出部では 国産品は 4.2 5.5 $\mathrm{mg} / 100 \mathrm{ml}$ で平均 $4.8 \mathrm{mg} / 100 \mathrm{ml}$ であり, ドイッのものは高い值の 1 点を除いても 5.5 $\sim 5.8 \mathrm{mg} / 100 \mathrm{~m} l$ でより高い值を示した。チ ェコのものは高い值を示し, 逆にアメリカの ものは最も低い。

酸性酢エチ抽出部は一般にバラッキが小さ
第 4 表 平均值および最高最低值 $(\mathrm{mg} / 100 \mathrm{ml})$

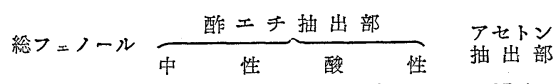

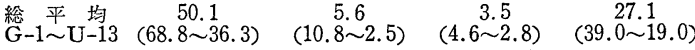
$\begin{array}{ccccc}\text { ドイッ平均 } & 59.2 & 6.4 & 3.7 & 28.5 \\ \mathrm{G}-1 \sim 4 & (68.8 \sim 46.9) & (8.9 \sim 5.5) & (4.0 \sim 3.1) & (35.8 \sim 20.0)\end{array}$ $\begin{array}{ccccc}\text { 日本平均 } & 46.4 & 46.4 & 4.8 & 3.3 \\ \mathrm{~J}-5 \sim 9 & (48.8 \sim 42.5) & (5.5 \sim 4.2) & (3.5 \sim 2.8) & (27.0 \sim 19.5)\end{array}$ い。この中でアメリカのものやや高い值を示し，イギリ スのものは 2 倍近い值であった。

アセトン抽出部は $19.0 \sim 39.0 \mathrm{mg} / 100 \mathrm{ml}$ の範囲にな る。国産のものは $19.5 \sim 27.0 \mathrm{mg} / 100 \mathrm{ml}$ で平均値とし ても低い。外国品にはかなり高い値を示すものがある。

IV. シリカカラムクロマトグラムの比較

各国のビン詰ビールの中性, 酸性酢酸エチル抽出部抒 よびアセトン抽出部のクロマトグラムを第 $1 〜 3$ 図に示 于े。

中性酢酸抽出部 各ビール共に主要ピークは共通して
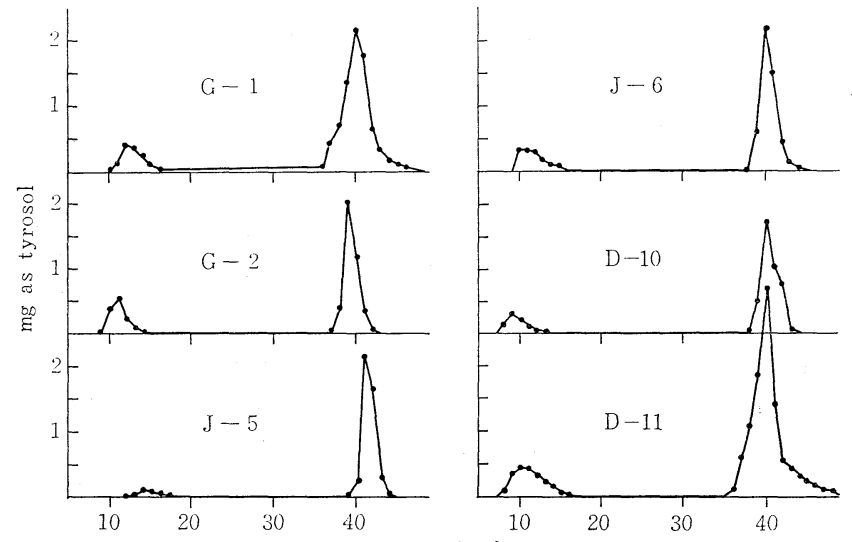

第1図酢エチ中性抽出部のクロマトグラム

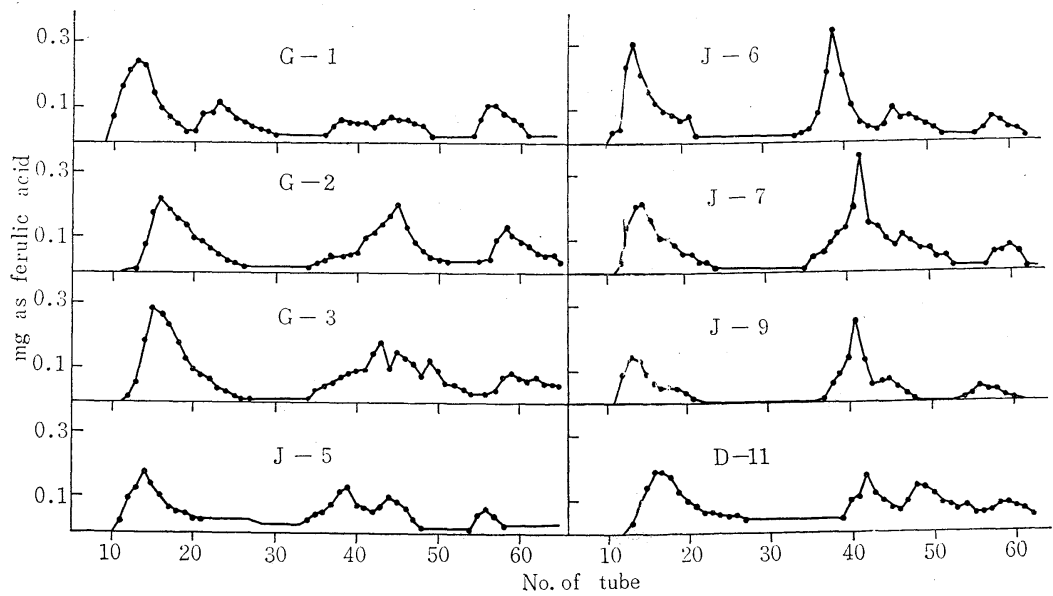

第 2 図酢エチ酸性抽出部のクロマトグラム 


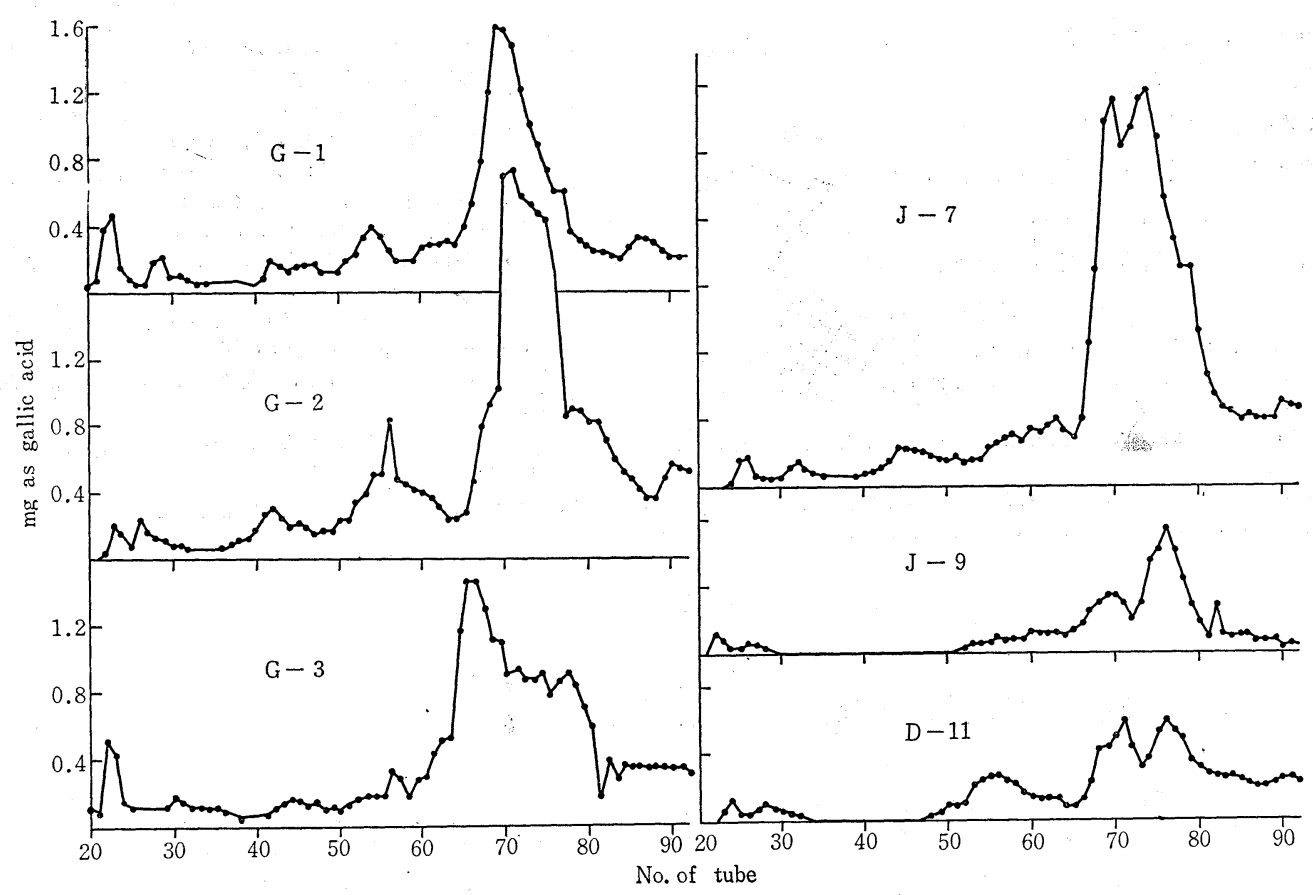

第 3 図 アセトン抽出部のクロマトグラム

第 5 表 シリカカラムクロマトグラムの各ピークのフェノール量 $(\mathrm{mg} / 100 \mathrm{ml})$

\begin{tabular}{|c|c|c|c|c|c|c|c|c|c|c|c|c|}
\hline ピーク & 酢エチ & 中性部 & & 酢エチ & 酸性部 & & & $\boldsymbol{T}$ & ト & 抽 & 出 部 & \\
\hline & 1 & 2 & 1 & 2 & 3 & 4 & 1 & 2 & 3 & 4 & 5 & 6 \\
\hline G- 1 & 0.60 & 4.15 & $\begin{array}{c}0.63 \\
(0.96)\end{array}$ & 0.20 & 0.23 & 0.27 & 0.66 & 0.44 & 0.52 & 1.13 & 10.26 & 0.83 \\
\hline G- 2 & 0.74 & 2.37 & 0.76 & 0.12 & 0.61 & 0.40 & 0.23 & 0.36 & 0.80 & 2.60 & 13.77 & 2.35 \\
\hline G- 3 & 0.79 & 1.57 & 0.87 & 0.49 & 0.45 & 0.20 & 0.59 & 0.23 & 0.32 & 0.72 & 9.86 & 1.26 \\
\hline$J-5$ & 0.28 & 2.31 & 0.49 & 0.38 & 0.21 & 0.11 & & & & & & \\
\hline$J-6$ & 0.72 & 2.68 & 0.69 & 0.56 & 0.24 & 0.13 & & & & & & \\
\hline$J-7$ & 1.04 & 1.44 & 0.61 & 0.69 & 0.23 & 0.12 & 0.26 & 0.33 & 0.81 & 1.73 & 13.44 & 0.98 \\
\hline$J-9$ & 0.53 & 2.85 & 0.37 & 0.36 & 0.10 & 0.08 & 0.14 & 0.06 & & 0.72 & 2.79 & 0.16 \\
\hline D-10 & 0.48 & 2.06 & 0.67 & 0.36 & 0.36 & 0.21 & 0.10 & & 0.62 & 1.71 & 5.53 & \\
\hline-11 & 1.21 & 5.15 & 0.08 & 0.38 & 0.28 & 0.36 & 0.12 & 0.20 & & 1.18 & 3.03 & 0.56 \\
\hline
\end{tabular}

は沪紙クロマトグラフィーで， $R_{f} 0.1$ 附近に紫外線を緑色の栄光を示すスポッ トが認められまた $R_{f} 0.3$ 附近には 2 ケのスポットが検出される。これは紫外 線吸収および蛍光並びにジアゾ試薬によ る呈色反応の結果, バニリン酸とフェル ラ酸に一致した。

第 2 ピークは沪紙クロマトで $R_{f} 0.9$ 附近に紫外線吸收はないが，ジアゾ試薬 で橙紫色に呈色するスポットが認められ る。その他のピークについては未検討で
2 ケ所に認められる。第 1 ピークはかなり香気の強い区 分で, 沪紙クロマトグラフィーを行うと $R_{f} 0.85$ 附近 に紫外線吸収（青色）を示すスポットがある。これはジ アゾ試薬では発色しない。この第 1 ピークは香気, 着色 度からみて他の多くの成分の存在が考兄られる。各ビー ル間の比較 (第 5 表) ではかなりの幅が認められる。

第 2 ピークは大部分がチロゾールであることが汇紙ク ロマトグラフィーの結果から明らかである。このものは 酵母の発酵生産物であるから, その量の差は発酵度合, 麦汁中のチロシン含量等が影響するものと考えられる。 この第 2 ピークの各ビールの比較ではドイッとデンマー クの各 1 点は多い含量を示した。

酸性酢酸エチル抽出部 主要なピークは 4 ケ所に認め られる。これらを 1 から 4 までとすると, 第 1 ピークに
ある。

ビール間の比較（第 5 表）では第 1 ピークはややドイ ッの方が多く，第 2 ピークは国産品の方が多い傾向があ る。第 3, 第 4 ピークとも国産品は少ない。この5ち J-9 は各ピーク共低めの值を示している。

デンマークの 2 点は第 1 ピークでかなり差がある（中 性部でも大きな差がある)。

アセトン抽出区分 主要ピークは 6 ケ所に認められ る。薄層クロマトグラフィー（シリカゲル, 溶媒, ブタ ノールー酢酸一水, $5: 1: 4)$ の結果の結果では第 4,5 ピ 一クには $R_{f} 0.5$ 附近に紫外線で青色の蛍光を示すスポ ットが顕著に見られる。

ビール間の比較では G-2 は J-7, G-1 と G-3, J-9 と D-11 は夫々類似のパターンを示す。特に最大ピーク 
（第 6 ピーク）では J-9, D-10, D-11 が他と比較して著 しく低い值であった。

このアセトン区分はビールの総フェノール量の半分近 くの值を占める区分であり，そのクロマトパターンの差 異はビールの官能的タイプの特徵になるかもしれない。 終りに試料を使用させて載いた各社に感謝します。

\section{文献}

1) G. HARRIS : JInst. Brew., 71, 292 (1965); G. HARRIS \& R. W. RicketTs : ibid., 61, 134 (1955) ; 64, 22 (1958); 65, 252 (1959)

2) L.Chapon et M.Chemardin: p.182, E.B.C., Brussel (1963)

3) W.D.MCFarlane et al. : J.Inst. Brew., 68, 254, 344 (1962)

4) N.S.CURTIS \& A.G. Clark : ibid., 67, 50 (1961)
5) J.R. A. Pollock : Rev. Ferm. Ind.aliment., 15, 171 (1960) : abst. J.Inst. Brew., 67, 278 (1961)

6) W. O.S. Meredith : Proc. A. M. Amer. Soc. Brew. Chem., 48 (1960) : abst. J.Inst. Brew., 67, 374 (1961)

7) G. KRAUSS \& H.E GNER : Brauwissenschaft, 13,178(1960): abst. J. Inst. Brew., 66, 422 (1960)

8) J.B. Woof \& J.S. PIERce : J.Inst. Brew., 72, 40 (1966)

9) T. Nakayama : Proc. A.M. Amer. Soc. Brew. Chem., 61 (1961) : abst. J. Inst. Brew., 68, 208 (1962)

10) P. Schmid \& W. KLEBER : Proc. E. B. C., Wien, 260 (1961): abst. J.Inst. Brew., 68, 360 (1962)

11) T. REYNOLDS et al. : ibid., 267(1961) : abst. J.Inst. Brewv., 67 (1962)

12) K. SCHUSTER \& H. RAAB : Brauwissenschaft, 14, 246 (1961); 15, 306 (1961)

13）大塚謙一，原 昌道，土辺美恵子：本誌，62，72 (1967)

J. Soc. Brew. Japan, 1971, Vol. 66, No. 2, p. $176 \sim$ p. 180

\title{
A Comparative Study on the Amount of Phenolic Substances in Commercial Lager Beer
}

\author{
by \\ K. Otsuka, C. K. Cheng \& M. Wakita \\ (Research Institute of Brewing, Tax Administration Agency, Kita-ku, Tokyo)
}

Commercial bottled beer was extracted successively with ethyl acetate (under neutral and acidic conditions) and acetone. Each extract was determined colorimetrically by using Folin-Denis reagent.

The authors considered the value of this procedure was mainly owing to the phenolic substances in beer and they named it the phenolic value.

The variation of phenolic value among individual batches in one factory, between brands in some factories and among foreign and Domestic brands was shown.

Moreover, each extract was chromatographed with silicic acid column. The resultant chromatogramms obtained from various brands of beer were summarized into 2 or 3 patterns. 